\title{
Correction: Obituaries Maxwell Caplin and Barron Bruce MacGillivray
}

BMJ 2011;343:d6558 doi:10.1136/bmj.d6558; BMJ 2011;343:d6420, doi:10.1136/bmj.d6420. Because of a production error, the two photographs accompanying these obituaries were swapped in the print $B M J$ (issue 22 October
2011, p 847). We apologise to the families of the deceased for the distress this must have caused them.

Cite this as: BMJ 2011;343:d6912

๑ BMJ Publishing Group Ltd 2011 